\title{
Clover Yellow Vein Virus and a Carlavirus Isolated from Impatiens sultani in Japan
}

\author{
XIANG Ben Chun*,**, Satoshi T. OHKI*,†, Takeshi OsakI* \\ and Tadao INOUYE*
}

Key words: Impatiens sultani, clover yellow vein virus, bean yellow mosaic virus, impatiens latent virus, identification, characterization.

Impatiens sultani is a widely grown ornamental plant, however, no virus has so far been described for it in Japan. In 1989, we detected two types of filamentous viruses in leaf-dip preparations from the plant collected in Osaka. This paper reports the characterization of a potyvirus and a carlavirus isolated from $I$. sultani which appeared necrotic ring symptom.

Clover yellow vein virus. A potyvirus, tentatively named as I89-1, was isolated from the diseased leaves showing necrotic ring symptom. It was mechanically transmitted to Phaseolus vulgaris $\mathrm{cv}$. Topcrop and subjected to three successive single lesion transfers on Chenopodium quinoa.

Mechanical inoculation experiment revealed that I89-1 had a wide host range and appeared nectrotic symptoms in most species. I89-1 was infectious to 16 species in 5 families. It systemically infected Chenopodium amaranticolor, C. quinoa, Glycine max, Nicotiana clevelandii, N. debneyi, Phaseolus vulgaris cv. Topcrop, Pisum sativum cv. Sanjunichi-kinusaya, Sesamum indicum, Trifolium repens, Vicia faba, Vigna unguiculata subsp. sesquipedalis cv. Kurodane-sanjaku. Species locally infected were Beta vulgaris, N. tabacum, Petunia hybrida, Spinacia oleracea, Tetragonia expansa, Vigna unguiculata cv. Daruma. The virus did not infect 16 species including Cucumis sativus, Gomphrena globosa and Pisum sativum cv. Wisconsin Perfection. The virus was also transmitted by Myzus presicae in non-persistent manner. The infected I. sultani appeared necrotic ring symptom (Plate I-1).

Filamentous virus particles $c .750 \mathrm{~nm}$ long and $12 \mathrm{~nm}$ wide were detected by electron microscopy in crude sap of the infected I. sultani. Fragments of pinwheel inclusions and rhombic, crystalline inclusions (dense body) ${ }^{1}$ were also observed in the leaf dip preparations negatively stained with $2 \%$ PTA, pH 6.5. In thin sections of the infected leaves of I. sultani or N.clevelandii, pinwheel- and laminated aggregate-type inclusions and crystalline inclusions as well as filamentous virus particles were observed in the cytoplasm (Plate I-2, 3).

I89-1 in crude sap of $I$. sultani or C. quinoa strongly reacted with the antisera to Cal. $35^{2 \text { ) }}$ and No. $30^{3)}$ isolates of clover yellow vein virus (CYVV) and to the $\mathrm{N}$ strain $\left.(\mathrm{P} 180)^{4}\right)$ of bean yellow mosaic virus (BYMV-N) in the double diffusion test (DDT) on $0.15 \%$ Gelrite gels ${ }^{5}$ (Plate I-4). The virus particles positively decorated with the antibodies were observed in the immuno-

* College of Agriculture, University of Osaka Prefecture, Sakai, Osaka 591, Japan 大阪府立大学 農学部

** Present address: Department of Agronomy, Shihezi Agricultural College, Shihezi, Xinjiang, China 現在: 中国新疆石河子農学院農学系

$\dagger$ To whom reprints should be requested.

1) Inouye, T. (1973). Nogaku Kenkyu 54: 155-171. 2) Inouye, N., Maeda, T. and Mitsuhata, K. (1988). Acta Hort. 234: 61-68. 3) Sato, A., Ohshima, K., Sano, T., Uyeda, I. and Shikata, E. (1987). J. Fac. Agr. Hokkaido Univ. 63: 277-286. 4) Inouye, T. (1968). Nogaku Kenkyu 52: 11-29. 5) Ohki, S.T. and Inouye, T. (1987). Ann. Phytopath. Soc. Japan 53: 557-561. 
sorbent electron microscopy (ISEM). On the other hand, I89-1 did not react with antiserum to B strain $\left.(\mathrm{V} 124)^{4}\right)$, $\mathrm{P}$ strain $(\mathrm{P} 242)^{4)}$ or $\mathrm{O}$ strain $(\mathrm{BH}-8)^{4)}$ of bean yellow mosaic virus by ISEM as well as DDT.

From these results, I89-1 was identified as $\mathrm{CYVV}^{6}$. $\mathrm{CYVV}$ has been isolated from many plant species, however, this may be the first report for I. sultani as the natural host of CYVV. The name "necrotic ring" is proposed for the disease of I. sultani by CYVV.

Host range study and other experiments showed that the isolate used in this study was identical to BYMV-N $\mathrm{N}^{4}$. The precipitin lines of the antigen to CYVV antisera and to BYMV-N antiserum were completely fused (Plate I-4). Therefore, it is concluded that BYMV-N is a synonym for CYVV ${ }^{2,3,6)}$. Since the name "BYMV-N" has been used only in Japan, it is recommendable to use "CYVV" for the virus.

A carlavirus. Another type of filamentous virus, tentatively named as I89-2, was detected in addition to I89-1 in the original $I$. sultani and also in $C$. quinoa which has been mechanically inoculated with the sap of $I$. sultani. Isolation of I89-2 was successfully conducted through single lesion transfers on C. quinoa.

In mechanical inoculation experiment using 38 species out of 11 families, only $C$. amaranticolor and $C$. quinoa were susceptible to I89-2 besides $I$. sultani. The virus produced local chlorotic spots on C. amaranticolor or C. quinoa 8-10 days after inoculation, however, no symptoms were observed on the infected I. sultani. Trials to transmit I89-2 from I. sultani to I. sultani or from C. quinoa to C. quinoa by Myzus persicae in the non-persistent condition were failed.

Slightly curved virus particles c. $640 \mathrm{~nm}$ long and $12 \mathrm{~nm}$ wide were detected by electron microscopy in the crude sap preparations negatively stained with $2 \% \mathrm{PTA}, \mathrm{pH} 6.5$. The filamentous particles were also observed in cytoplasm of the infected I. sultani or C. quinoa.

I89-2 was purified from the inoculated leaves of $C$. quinoa (Plate I-6). The extract was clarified by chroloform and carbon tetrachloride. Then, the virus was precipitated by PEG 6,000 and purified by differential and sucrose density gradient centrifugation. Purified I89-2 had an absorption spectrum typical of nucleoprotein with a minimum absorbance at $242 \mathrm{~nm}$ and a maximum at $258 \mathrm{~nm}$ with a $A_{260} / A_{280}$ ratio of 1.22. Single band with a buoyant density of $1.32 \mathrm{~g} / \mathrm{cm}^{3}$ was obtained for the virus in the equilibrium $\mathrm{CsCl}$ density gradient.

The orcinol, the diphenylamine and the formaldehyde treatments indicated that the extracted nucleic acid preparation was single-stranded RNA. Polyacrylamide gel electrophoresis under denaturing conditions revealed that the RNA consisted of single component with a molecular weight of $c .1 .9 \times 10^{6}$ daltons. Protein of the virus electrophoresed in SDS-polyacrylamide gel migrated as one band with a molecular weight of $c .34,000$ daltons.

Antiserum prepared against I89-2 in a rabbit had a titer of $1 / 1,024$ with the purified virus preparation in microprecipitin test. I89-2 did not react with antisera to any of the following viruses in gel diffusion tests: carnation latent virus ${ }^{7)}$, garlic latent virus ${ }^{8}$, helenium virus $\mathbf{S}(\mathbf{H V S})^{9}$, shallot latent virus ${ }^{10)}$ and strawberry pseudo mild yellow edge virus (SPMYEV) ${ }^{11)}$. However, I89-2 reacted with antiserum to SPMYEV by the immunosorbent electron microscopy to a dilution of $1 / 200$ (Plate I-7).

The results obtained in this study strongly indicated that I89-2 is a carlavirus. Although it related to SPMYEV and has a common natural host with HVS, it is considered that the virus is an undescribed virus because of its very specific host reactions. The name impatiens latent virus is proposed for the virus. Since $I$. sultani is an annual plant in Japan, the virus might be transmitted to it from another natural host by an unknown means.

6) Hollings, M. and Stone, O.M. (1974). CMI/AAB Descriptions of Plant Viruses No. 131. 7) Tochihara, H., Idei, T., Yabuki, S. and Fukumoto, F. (1975). Ann. Phytopath. Soc. Japan 41: 390-399. 8) Sako, I., Nakasone, W., Okada, K., Osaki, T. and Inouye, T. (1989). Proc. Kansai Pl. Prot. 31: 23-29. 9) Koenig, R., Lesemann, D.-E., Lockhart, B., Betzold, J.A. and Weidemann, H.L. (1983). Phytopath. Z. 106: 133-140. 10) Bos, L., Huttinga, H. and Maat, D.Z. (1978). Neth. J. Pl. Path. 84: 227-237.

11) Yoshikawa, N. and Inouye, T. (1986). Ann. Phytopath. Soc. Japan 52: 643-652. 
The authors are grateful to Drs. Bos, L., Inouye, N., Koenig, R., Tochihara, H., Uyeda, I. for providing antisera to shallot latent virus, CYVV-Cal. 35, helenium virus $\mathrm{S}$, carnation latent virus and CYVVNo. 30 , respectively.

\section{和 文 摘 要}

向 本春・大木 理・尾崎武司・井上忠男：日本の Impatiens sultani から分離された clover yellow vein virus ならびに carlavirus について

穵輪紋病徴を示すインパチェンスから 2 種のひも状ウイルスが分離されたので同定を試みた。一つは長 さ $750 \mathrm{~nm}$ の potyvirus で，インパチェンスにはえそ輪紋病徵を表し，諸性質から clover yellow vein virus と同定された。ウイルス和名をクローバ葉脈黄化ウイルス，インパチェンス病名をえそ輪紋病 (necrotic ring) としたい。第 2 のウイルスは長さ約 $640 \mathrm{~nm}$ の carlavirus で, インパチェンスに無病徵感染したほか Chenopodium amaranticolor と C. quinoa に局部感染した。精製ウイルスの理化学的性質は既報の carlavirus にほぼ一致し，5種の carlavirus のうち, strawberry pseudo mild yellow edge virus とのみ免疫電顕法で遠 い血清関連が認められた。未記載ウイルスと考えられるのでウイルス名としてインパチェンス潜在ウイルス (impatiens latent virus) を提案したい。

(Received February 19, 1990)

Plate I

\section{Explanation of plate}

1. Necrotic rings appeared on systemic leaves of Impatiens sultani infected with I89-1 (clover yellow vein virus, potyvirus), 18 days after inoculation.

2. Pinwheel- and laminated aggregate-type inclusions observed in cytoplasm of a leaf parenchyma cell of $I$. sultani infected with I89-1.

3. Crystalline inclusions and laminated aggregates (arrows) appeared in cytoplasm of a leaf parenchyma cell of $I$. sultani infected with I89-1.

4. Double diffusion test performed in $0.15 \%$ Gelrite gel. The central well contains crude sap of I. sultani infected with I89-1 (AG). Outer wells are the antisera of bean yellow mosaic virus (BYMV) and clover yellow vein virus (CYVV): B, BYMV-B (V124); P, BYMV-P (P242); O, BYMV-O (BH-8); N, BYMV-N (P180); C1, CYVV-Cal.35; C2, CYVV-No. 30. Rings around the outer wells are formed by non-specific reaction. Precipitation between $\mathrm{O} / \mathrm{P}$ and $\mathrm{AG}$ are due to antibodies to the healthy components.

5. Chlorotic spots appeared on a inoculated leaf of Chenopodium amaranticolor infected with I89-2 (impatiens latent virus, carlavirus), 10 days after inoculation.

6. Purified virus particles of I89-2.

7. Virus particles of I89-2 decorated with the antiserum to strawberry pseudo mild yellow edge virus at a dillution of $1 / 100$.

Bar represents $200 \mathrm{~nm}$ in Figs. 2, 3, 6 and 7. 
Plate I

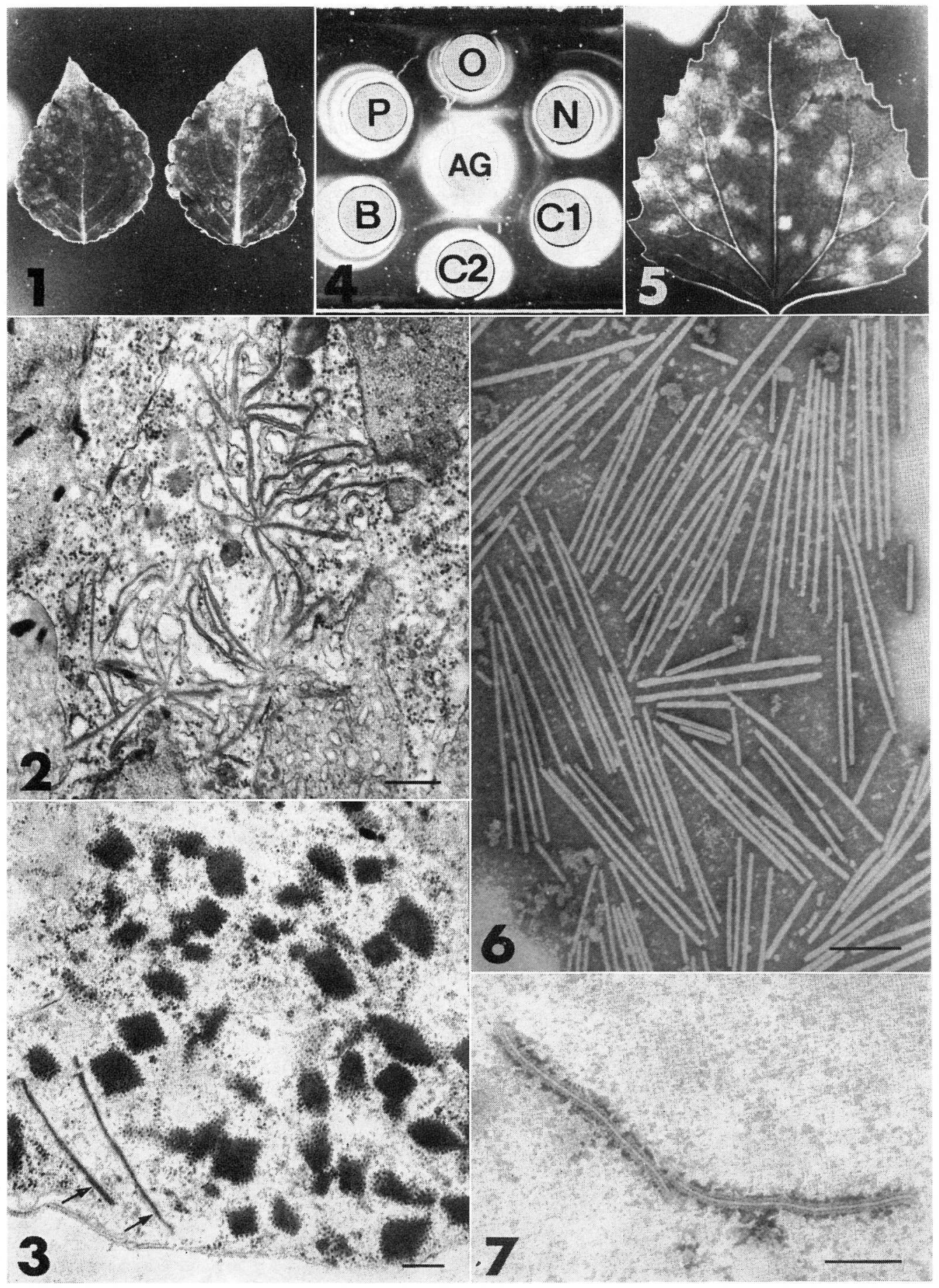

